\title{
ANALISA PERBEDAAN KINERJA KEUANGAN PEMERINTAH KOTA KEDIRI SEBELUM DAN SESUDAH PEMBERLAKUAN ANGGARAN BERBASIS KINERJA
}

\author{
Oleh: \\ Widyastuti Ayu Lestari \\ Staff Sekretariat Daerah Kota Batu \\ E-mail/No. Hp: ayoe_w1dy4@yahoo.com/085646445970
}

\begin{abstract}
Target of this research is to find empirical evidence of differentiation of monetary independence storey and fiscal decentralization Government of Kediri before and after application of budget base on performance. Method which used in this research is monetary ratio consisting of independence ratio. fiscal decentralization. efficiency ratio and effectiveness ratio, for knowing monetary independence storey of region, fiscal decentralization storey; effectiveness and efficiency of PAD which workable of government. From calculation of the monetary ratio different test by using $F$-Test to know the existence of difference before and after application of budget based on performance. Result of calculation showed monetary independence storey is existence of difference before and after application of budget base on performance, fiscal decentralization storey there isn't differentiation before and after application of budget base on performance, effectiveness storey of PAD and efficiency storey of PAD experiencing of difference before and after application of budget base on performance.
\end{abstract}

Keywords: fiscal decentralization, efficiency, and Kediri

\section{PENDAHULUAN}

Otonomi daerah di Indonesia yang didasarkan pada undang-undang nomor 22 tahun 1999 juncto undang-undang nomor 32 tahun 2004 tentang pemerintah daerah dan undang-undang nomor 25 tahun 1999 juncto undang-undang nomor 33 tentang perimbangan keuangan antara pusat dan daerah dengan sistem pemerintahan desentralisasi sudah mulai efektif dilaksanakan sejak 1 januari 2001. Undang-undang tersebut merupakan kebijakan yang dipandang sangat demokratis dan memenuhi aspek desentralisasi pemerintah yang sesungguhnya.

Pertimbangan mendasar terselenggaranya Otonomi Daerah (Otoda) adalah perkembangan kondisi di dalam negeri yang mengindikasikan bahwa rakyat menghendaki keterbukaan dan kemandirian (desentralisasi). Selain itu keadaan luar negeri yang juga menunjukkan bahwa semakin maraknya globalisasi yang menuntut daya saing tiap negara, termasuk daya saing pemerintah daerahnya. Daya saing pemerintah daerah ini diharapkan akan tercapai melalui peningkatan kemandirian pemerintah daerah. Selanjutnya peningkatan kemandirian pemerintah daerah tersebut diharapkan dapat diraih melalui Otoda (Halim 2001:2). Tujuan program otonomi daerah adalah mempercepat pertumbuhan ekonomi dan pembangunan daerah, mengurangi kesenjangan antar daerah dan meningkatkan kualitas pelayanan publik 
agar lebih efisien dan responsif terhadap kebutuhan, potensi maupun karakteristik di daerah masingmasing. Hal ini ditempuh melalui peningkatan hak dan tanggung jawab pemerintah daerah untuk mengelola rumah tangganya sendiri. (Bastian 2006).

Adapun misi utama undangundang nomor 33 tahun 2004 tersebut bukan hanya keinginan untuk melimpahkan kewenangan pembangunan dari pemerintah pusat dan pemerintah daerah, tetapi yang lebih penting adalah efisiensi dan efektifitas sumber daya keuangan. Untuk itu diperlukan suatu laporan keuangan yang handal dan dapat dipercaya agar dapat menggambarkan sumber daya keuangan daerah berikut dengan analisis prestasi pengelolaan sumber daya keuangan daerah itu sendiri (Bastian 2001:6). Hal tersebut sesuai dengan ciri penting dari suatu daerah otonom yang mampu menyelenggarakan otonomi daerahnya yaitu terletak pada strategi sumber daya manusia (SDM) dan kemampuan di bidang keuangan daerah (Soedjono 2000).

Analisis prestasi dalam hal ini adalah kinerja dari pemerintah daerah itu sendiri dapat didasarkan pada kemandirian dan kemampuannya untuk memperoleh, memiliki, memelihara dan memanfaatkan keterbatasan sumbersumber ekonomis daerah untuk memenuhi seluas-luasnya kebutuhan masyarakat di daerah. Seperti yang diungkapkan Soedjono (2000) dalam penelitiannya dengan objek penelitian pemerintah kota Surabaya bahwa sebagai daerah otonom, daerah mempunyai kewenangan dan tanggung jawab menyelenggarakan kepentingan masyarakat menurut prakarsa sendiri berdasarkan prinsip-prinsip keterbukaan, partisipasi masyarakat, dan pertanggungjawaban kepada masyarakat dalam rangka menciptakan pemerintahan yang baik (good governance).

Untuk mewujudkan good governance diperlukan perubahan paradigma pemerintahan yang mendasar dari sistem lama yang serba sentralistis, dimana pemerintah pusat sangat kuat dalam menentukan kebijakan. Paradigma baru tersebut menuntut suatu sistem yang mampu mengurangi ketergantungan dan bahkan menghilangkan ketergantungan pemerintah daerah kepada pemerintah pusat, serta bisa memberdayakan daerah agar mampu berkompetisi baik secara regional, nasional maupun internasional. Menanggapi paradigma baru tersebut maka pemerintah memberikan otonomi kepada daerah seluas-luasnya yang bertujuan untuk memungkinkan daerah mengurus dan mengatur rumah tangganya sendiri agar berdaya guna dan berhasil guna dalam penyelenggaraan pemerintahan dan pembangunan serta dalam rangka pelayanan kepada masyarakat. Penyelenggaraan otonomi daerah dilaksanakan dengan memberikan otonomi seluas-luasnya dan secara proporsional kepada daerah yang diwujudkan dengan adanya pengaturan, pembagian dan pemanfaatan sumber daya nasional yang berkeadilan serta adanya perimbangan keuangan antara pusat dan daerah.

Proses penyusunan anggaran sektor publik umumnya disesuaikan dengan peraturan lembaga yang lebih tinggi. Sejalan dengan pemberlakuan Undang-Undang Nomor 22 Tahun 1999 tentang Pemerintahan Daerah dan Undang-Undang Nomor 25 tentang Perimbangan Keuangan antara Pemerintah Pusat dan Daerah, yang direvisi menjadi UU No 32 Tahun 2004 tentang Pemerintahan Daerah dan UU No 33 Tahun 2004 tentang Perimbangan Keuangan antara Pemerintah Pusat dan Daerah, lahirlah tiga paket perundang- 
undangan, yaitu UU No 17/2003 tentang Keuangan Negara, UU No 1/2004 tentang Perbendaharaan Negara, dan UU No 15/2004 tentang Pemeriksaan Pengelolaan dan Tanggung Jawab Keuangan Negara, yang telah membuat perubahan mendasar dalam penyelenggaraan pemerintahan dan pengaturan keuangan, khususnya Perencanaan dan Anggaran Pemerintah Daerah dan Pemerintah Pusat. Kemudian, saat ini keluar peraturan baru yaitu PP 58/2005 tentang Pengelolaan Keuangan Daerah dan Permendagri 13/2006 tentang Pedoman Pengelolaan Keuangan Daerah, yang akan menggantikan Kepmendagri nomor 29 tahun 2002.

Dalam reformasi anggaran tersebut, proses penyusunan APBD diharapkan menjadi lebih partisipatif. Hal tersebut sesuai dengan Keputusan Menteri Dalam Negeri nomor 29 tahun 2002 pasal 17 ayat 2, yaitu dalam menyusun arah dan kebijakan umum APBD diawali dengan penjaringan aspirasi masyarakat, berpedoman pada rencana strategis daerah dan dokumen perencanaan lainnya yang ditetapkan daerah, serta pokok-pokok kebijakan nasioanal dibidang keuangan daerah. Selain itu sejalan dengan yang diamanatkan dalam undangundang nomor 17 tahun 2003 tentang perimbangan keuangan negara akan pula diterapkan secara penuh anggaran berbasis kinerja di sektor publik agar penggunaan anggaran tersebut bisa dinilai kemanfaatan dan kegunaannya oleh masyarakat (Abimanyu 2005).

$$
\text { Undang-Undang Nomor } 17
$$
menetapkan bahwa APBD disusun berdasarkan pendekatan prestasi kerja yang akan dicapai. Untuk mendukung kebijakan ini perlu perlu dibangun suatu sistem yang dapat menyediakan data dan informasi untuk menyusun APBD dengan pendekatan kinerja. Anggaran kinerja pada dasarnya merupakan sistem penyusunan dan pengelolaan anggaran daerah yang berorientasi pada pencapaian hasil atau kinerja. Adapun kinerja tersebut harus mencerminkan efisiensi dan efektifitas pelayanan publik, yang berarti harus berorientasi pada kepentingan publik (Mariana 2005). Tetapi dalam mengimplementasikan Keputusan Menteri Dalam Negeri nomor 29 tahun 2002 tersebut masih banyak pemerintah daerah yang mengalami kesulitan karena kurangnya pelatihan dan pendampingan dari pemerintah pusat. Hal tersebut dapat mengindikasikan bahwa belanja aparatur lebih tinggi dibandingkan dengan belanja publik (Roesman dan Dendis 2005).

Perkembangan kondisi umum perekonomian merupakan gambaran umum perkembangan perekonomian daerah, yang secara tidak langsung juga merupakan gambaran prestasi Pemerintah Kota dalam meningkatkan kesejahteraan rakyat. Perkembangan perekonomian daerah dapat dipengaruhi dinamika perkembangan perekonomian nasional. Meski demikian, adanya kesenjangan perkembangan perekonomian nasional dan daerah tersebut, diharapkan dapat menjadi stimulus bagi semua pihak yang memiliki tanggung jawab dan komitmen dalam meningkatkan kondisi ekonomi daerah.

Tingkat Pertumbuhan ekonomi Kota Kediri pada tahun 2004-2007 mengalami kenaikkan, perekonomian mengalami pertumbuhan sebesar $7,17 \%$ pada tahun $2004,4,32 \%$ pada tahun 2005, 4,21\% pada tahun 2006 dan pada tahun 2007 sebesar 4,32\%. Pertumbuhan ekonomi Kota Kediri juga dipengaruhi adanya Gudang Garam yang berada di Kota kediri. Dilihat dari tingkat pertumbuhan ekonomi tersebut dapat 
menilai pemerintah Kota Kediri dalam melaksanakan anggaran berbasis kinerja.

Berdasarkan latar belakang, dalam penelitian ini penulis mengemukakan beberapa rumusan masalah yaitu 1) Bagaimana tingkat kemandirian keuangan dan tingkat desentralisasi fiskal pemerintah Kota Kediri antara sebelum dan sesudah pemberlakuan anggaran berbasis kinerja? 2) Bagaimana tingkat efisiensi PAD Pemerintah Kota Kediri antara sebelum dan sesudah pemberlakuan anggaran berbasis kinerja? 3)Apakah ada perbedaan tingkat efektivitas PAD dan efisiensi PAD Pemerintah Kota Kediri

\section{TINJAUAN PUSTAKA}

Dalam organisasi sektor publik adanya anggaran sebagai managerial plan for action sangat penting untuk tercapainya tujuan organisasi. Menurut Mardiasmo (2002:61) anggaran merupakan pernyataan mengenai estimasi kinerja yang hendak dicapai selama periode waktu tertentu yang dinyatakan dalam ukuran finansial.

Sedangkan Bastian (2006:164) yang mengutip dari National Committe on Governmental Accounting (NCGA), yaitu rencana operasi keuangan yang mencakup estimasi pengeluaran yang diusulkan, dan sumber pendapatan yang diharapkan untuk membiayainya dalam periode waktu tertentu.

Anggaran adalah suatu proses menyusun rencana keuangan, yaitu pendapatan dan pembiayaan, kemudian mengalokasikan dana tersebut ke masing-masing kegiatan sesuai dengan fungsi dan sasaran yang hendak dicapai. Masing-masing kegiatan tersebut kemudian dikelompokkan ke dalam program berdasarkan tugas dan tanggung jawab dari satuan kerja tertentu.

Mardiasmo (2002), mengungkapkan ada beberapa fungsi utama dari adanya anggaran sektor publik.
Anggaran sebagai alat perencanaan (Planing Tool) adalah anggaran yang merupakan alat perencanaan untuk mencapai tujuan organisasi. Anggran sektor publik dibuat untuk merencanakan tindakan apa yang akan dilakukan oleh pemerintah, berapa biaya yang dibutuhkan, dan berapa hasil yang diperoleh dari belanja pmerintah tersebut untuk.

Anggaran sebagai alat pengendalian (Control Tool) adalah anggaran yang memberikan rencana detail atas pendapatan dan pengeluaran pemerintah agar pembelanjaan yang dilakukan dapat dipertanggungjawabkan kepada publik.

Anggaran sebagai alat kebijakan fiskal (Fiskal Tool) adalah anggaran yang digunakan untuk menstabilkan ekonomi dan mendorong pertumbuhan ekonomi.

Anggaran sebagai alat politik (Political Tool) adalah anggaran yang digunakan untuk memutuskan prioritasprioritas dan kebutuhan keuangan terhadap prioritas tersebut. Pada sektor publik, anggaran merupakan dokumen politik sebagai bentuk komitmen eksekutif dan kesepakatan legislatif atas penggunaan dana publik untuk kepentingan tertentu.

Anggaran sebagai alat kordinasi dan komunikasi (Cordination \& Communication Tool) adalah anggaran publik yang disusun dengan baik akan mampu mendeteksi terjadinya inkonsistensi suatu unit kerja dalam pencapaian tujuan organisasi.

Anggaran sebagai alat penilaian kinerja (Performance Measurement Tool) adalah anggaran yang merupakan wujud komitment dari budget holder (eksekutif) kepada pemberi wewenang (legislatif). Kinerja eksekutif akan dinilai berdasarkan pencapaian target anggaran dan efisiensi pelaksanaan anggaran. Kinerja manajer dinilai berdasarkan 
berapa yang berhasil ia capai dikaitkan dengan anggaran yang telah ditetapkan.

Anggaran sebagai alat motivasi (Moltivation Tool) adalah anggaran yang dapat digunakan sebagai alat untuk memotivasi manajer dan stafnya agar bekerja secara ekonomis, efektif, dan efisien dalam pencapaian target dan tujuan organisasi yang telah ditetapkan.

Anggaran sebagai alat menciptakan ruang publik (Publik Sphere) adalah anggaran pemerintah yang digunakan untuk kepentingan kelompok masyarakat yang terorganisir dan kelompok yang kurang terorganisir akan mempercayakan aspirasinya melalui proses politik yang ada.

Adapun tipe dari anggaran menurut Bastian (2006:166) adalah sebagai berikut: Line Item Budgeting adalah penyusunan anggaran yang didasarkan pada dari mana dana berasal (pos-pos penerimaan) dan untuk apa dana tersebut digunakan (pos-pos pengeluaran). Jenis anggran ini relatif dianggap paling tua dan banyak mengandung kelemahan atau sering disebut traditional bugeting.

Planning Progamming Budgeting System adalah suatu proses perencanaan, pembuatan program, dan penganggaran, serta di dalamnya terkandung identifikasi tujuan organisasi atas permasalahan yang mungkin timbul.

Zero Based Budgeting merupakan sistem anggaran yang didasarkan pada perkiraan kegiatan, bukan pada apa yang telah dilakukan di masa lalu, dan setiap kegiatan dievaluasi secara terpisah.

Performance Budgeting adalah sistem penganggaran yang berorientasi pada output organisasi dan berkaitan erat dengan Visi, Misi, dan Rencana Strategis Organisasi.

Medium Term Budgeting Framework adalah suatu kerangka strategi kebijakan pemerintah tentang anggaran belanja untuk departemen dan lembaga non departemen, dan kerangka tersebut memberikan tanggung jawab yang lebih besar kepada departemen untuk penetapan alokasi dan penggunaan sumber dana pembangunan.

Menurut Keputusan Menteri Dalam Negeri nomor 29 tahun 2002 Anggaran Pendapatan Belanja Daerah (APBD) dalam era otonomi daerah disusun dengan pendekatan kinerja, artinya sistem anggaran yang mengutamakan pencapaian hasil kinerja atau keluaran (output) dari perencanaan alokasi biaya yang telah ditetapkan. Dengan demikian diharapkan penyusunan dan pengalokasian anggaran dapat lebih disesuaikan dengan skala prioritas dan preferensi daerah yang bersangkutan (Bastian:2006). Sedangkan anggaran kinerja menurut Halim (2004:139) adalah anggaran yang disusun dengan pendekatan kinerja, yang memuat sasaran yang diharapkan menurut fungsi belanja, standar pelayanan yang diharapkan dan perkiraan biaya satuan komponen kegiatan yang bersangkutan, dan bagian pendapatan APBD yang membiayai belanja administrasi umum, belanja operasi dan pemeliharaan, belanja modal/pembangunan, belanja bagi hasil dan bantuan keuangan, dan belanja tidak tersangka.

Penerapan anggaran kinerja dalam sistem penganggaran daerah dilatarbelakangi oleh hal-hal berikut 1) Meningkatnya tuntutan masyarakat terhadap pengelolaan keuangan daerah secara transparan dan memenuhi prisnip akuntabilitas publik; 2)Sistem, prosedur, format dan struktur APBD yang berlaku selama ini tidak mampu mendukung tuntutan perubahan; dan 3) Terdapat upaya yang kuat untuk mensinergikan hubungan antara APBD, sistem dan prosedur pengelolaan keuangan daerah, 
lembaga pengelola keuangan daerah dan unit-unit pelayanan publik.

Ciri-ciri pokok dari dari sistem anggaran berbasis kinerja menurut Bastian (2006:53) adalah 1)Secara umum sistem anggaran kinerja mengandung tiga unsur pokok, yaitu: (i) pengeluaran pemerintah diklasifikasikan menurut program dan kegiatan; (ii) performance measurement atau pengukuran hasil kerja; dan (iii) program reporting (pelaporan program). 2) Titik perhatian lebih ditekankan pada pengukuran hasil kerja, bukan pada pengawasan. 3) Setiap kegiatan harus dilihat dari sisi efisiensi dan memaksimumkan output. 4) Bertujuan untuk menghasilkan informasi biaya dan hasil kerja yang dapat digunakan untuk penyusunan target evaluasi pelaksanaan kerja.

Keunggulan dari anggaran berbasis kinerja menurut Bastian (2006:53) adalah 1) Memungkinkan pendelegasian wewenang dalam pengambilan keputusan; 2)Merangsang partisipasi dan memotivasi satuan kerja melalui proses pengusulan dan penilaian anggaran bersifat faktual; 3) Membantu fungsi perencanaan dan mempertajam pembuatan keputusan; 4) Memungkinkan alokasi dana secara optimal dengan didasarkan efisiensi satuan kerja; 5)Menghindari pemborosan.

APBD dengan pendekatan kinerja harus memuat beberapa hal menurut Bastian (2006:53) adalah 1) Sasaran yang diharapkan menurut fungsi belanja; 2) Standar pelayanan yang diharapkan dan perkiraan biaya satuan komponen kegiatan yang bersangkutan; 3) Persentase dari jumlah pendapatan APBD yang mendanai pengeluaran administrasi umum, operasi dan pemeliharaan serta belanja modal/pembangunan.

Pengukuran kinerja sangat penting untuk menilai akuntanbilita organisasi dan manajer dalam menghasilkan pelayanan publik yang lebih baik. Menilai akuntanbilitas untuk menunjukkan bahwa uan tersebut telah dibelanjakan secara ekonomis, efisien, dan efektif. Pengukran kinerja membantu pemerintah daerah dalam menentukan tingkat pencapaian tujuan. Ukuran kinerja juga membantu warga untuk mengevaluasi apakah tingkat pelayanan pemerintah sudah sesuai dengan apa yang diinginkan oleh warga.

Pengukuran sektor publik dilakukan untuk dapat membantu pemerintah berfokus pada tujuan dan sasaran program kerja. Hal ini akan meningkatkan efisiensi dan efektivitas sektor publik dalam pemberian pelayanan publik. Kinerja sektor publik bersifat multidimensional, sehingga tidak ada indikator tunggal yang dapat digunakan untuk menunjukkan kinerja secara komprehensif (Hyaul Ulum, 2004:276).

Adapun manfaat pengukuran kinerja yaitu pertama Memberikan pemahaman mengenai ukuran yang digunakan untuk menilai kinerja manajemen; kedua Memberikan arah untuk mencapai target kinerja yang telah ditetapkan; ketiga Untuk memonitor dan mengevaluasi pencapaian kinerja dan membandingkannya dengan target kinerja serta melakukan tindakan korektif untuk memperbaiki kinerja; keempat Membantu mengidentifikasikan apakah kepuasan pelanggan sudah terpenuhi; kelima Membantu memahami proses kegiatan instansi pemerintah; keenam Untuk memastikan pengambilan keputusan dilakukan secara obyektif.

Pengukuran kinerja yang dilihat berdasarkan pada Lembaga Adminstrasi Negara (LAN): aspek finansial, aspek finansial, operasi bisnis internal, kepuasan pegawai,kepuasan komunitas dan stakeholders, waktu. 
Sektor publik dinilai sebagai pemborosan, sumber kebocoran dana dan instusi yang selalu merugi. Value for money merupakan konsep pengelolaan organisasi sektor publik yang mendasarkan pada tiga elemen pokok, yaitu: ekonomi, efisiensi, dan efektivitas. Value for money dapat tercapai apabila organisasi telah telah menggunakan biaya input paling kecil untuk mencapai output yang optimum dalam rangka mencapai tujuan organisasi (Ulum, 2004:274).

Manfaat dari implementasi konsep value for money pada organisasi sektor publik antara lain 1)Dapat meningkatkan efektivitas pelayanan publik; 2)Meningkatkan mutu pelayanan publik; 3)Menurunkan biaya pelayanan publik karena hilangnya inefisiensi dan terjadinya penghematan dalam penggunaan input; 4) Alokasi belanja yang lebih berorientasi pada kepentingan publik; dan 5) Meningkatkan kesadaran akan uang publik sebagai akar pelaksanaan akuntanbilitas publik.

Indikator value for money dibagi menjadi dua bagian, yaitu indicator alokasi biaya (ekonomi dan fisien); dan indicator kualitas pelayanan (efektivitas). Berikut ini akan dijelaskan megenai konsep value for money atau yang dikenal dengan 3E (EkonomiEfisien-Efektif) (Mardiasmo, 131; 2002)

Ekonomi berarti hubungan antara pasar dan masukan (cost of input), atau ekonomi adalah praktik pembelian barang dan jasa input dengan tingkat kualitas tertentu pda harga terbaik yang dimungkinkan (spending less). Pengertian ekonomi sering disebut kehematan yang mencakup juga pengelolaan secara hati-hati atau cermat (prudency) dan tidak ada pemborosan. Suatu kegiatan operasional dikatakan ekonomis bila dapat mengurangi biaya yang tidak perlu.
Efisiensi berhubungan erat dengan konsep produktivitas. Pegukuran efisiensi dilakukan dengan menggunakan perbandingan antara output yang dihasilkan terhadap input yang digunakan (cost of output). Proses kegiatan operasional dapat dikatakan efisien apabila suatu produk tertentu dapat dicapai dengan penggunaan sumberdaya dan dana yang serendahrendahnya (spending well). Indikator efisiensi menggambarkan hubungan antara masukan sumberdaya oleh suatu unit organisasi dan keluaran yang dihasilkan. Indikator tersebut memberikan informasi tentang konversi masukan menjadi keluaran.

Efektivitas pada dasarnya berhubugan dengan pencapaian tujuan atau target kebijakan (hasil guna). Efektivitas merupakan hubungan antara keluran dengan tujuan atau sasaran yang harus dicapai. Kegiatan operasional dikatakan efektif apabila proses kegiatan mencapai tujuan dan sasaran akhir kebijakan (spending wiswly). Indikator efektivitas menggambarkan jangkauan akibat dan dampak dari keluaran program dalam mencapai tujan program. Semakin besar kontribusi output yang dihasilkan terhadap pencapaian tujuan atau sasaran yang ditentukan, maka semakin efektif proses kerja suatu unit produksi.

Dalam melakukan pengukuran kinerja, informasi yang digunakan dikelompokkan menjadi dua.

Informasi Finansial Penilaian laporan kinerja finansial berdasarkan pada anggaran yang sudah dibuat. Penilain dilakukan dengan menganalisis varians (selisih atau perbedaan) antara kinerja aktual dengan yang dianggarkan. Setelah dilakukan varians, dilakukan identifikasi sumber penyebab terjadinya varians. Hal tersebut dilakukan untuk mengetahui unit spesifik mana yang 
bertanggung jawab terhadap terjadinya varians.

Informasi Non-Finansial Teknik pengukuran kinerja yang komprehensif yang banyak dikembangkan adalah Balanced Scorecard. Dengan Balanced Scorecard kinerja diukur tidak hanya berdasarkan aspek finansial tetapi juga aspek non-finansial. Pengukuran dengan metode Balanced Scorecard melibatkan empat aspek, yaitu Perspektif finansial, Perspektif kepuasan pelanggan, Perspektif efisiensi proses internal, Perspektif pembelajaran dan pertumbuhan.

Indikator kinerja Indikator kinerja diartikan sebagai ukuran kuantitatif atau kualitatif yang menggambarkan tingkat pencapaian suatu sasaran tujuan yang telah ditetapkan. Indikator kinerja harus merupakan suatu yang dapat diukur dan digunakan sebagai dasar untuk menilai kinerja, baik dalam tahap perencanaan, (ex-ante), tahap pelaksanaan (on-going), maupun tahap setelah kegiatan (ex-post).

Indikator untuk setiap unit organisasi berbeda-beda tergantung pada tipe pelayanan yang dihasilkan. Penentuan indikator kinerja perlu mempertimbangkan komponen Biaya pelayanan; Penggunaan; Kualitas dan standar pelayanan; Cakupan pelayanan; Kepuasan.

\section{METODE PENELITIAN}

Setiap kegiatan pemerintah dianalisis manfaat dan biaya yang dikeluarkan, setiap instansi pengguna anggaran wajib melaporkan kinerjanya. Usaha-usaha untuk menggali sumbersumber pendapatan daerah, mengalami berbagai kendala, baik dari segi keterbatasan sumber dana itu sendiri maupun dari segi kemampuan dan sistem pengelolaan serta administrasi keuangan daerah. Untuk itulah sumber-sumber penerimaan daerah yang tersedia sebaiknya dikelola secara efisien dan efektif, namun disaat bersamaan terdapat juga kendala-kendala dalam pengelolaannya.

Dalam menganalisa data pada penelitian ini penulis membuat tahaptahap teknik analisis yaitu: (Halim:234)

Untuk mencari tingkat kemandirian,

RasioKemandirian $=\frac{\text { BantuanPendapa } \tan \text { aht } \text { Asusat } / \operatorname{Pr} \text { opinsidanPinjaman }}{\text { Bation }}$

Rasio kemandirian menggambarkan ketergantungan daerah terhadap sumber dana eksternal. Semakin tinggi rasio kemandirian maka tingkat kemandirian semakin baik.

Perhitungan rasio-rasio keuangan yang merupakan alat ukur kinerja keuangan, yaitu terdiri dari :

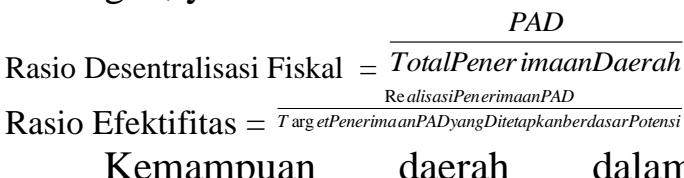
menjalankan tugas dikategorikan efektif apabila rasio yang dicapai mencapai minimal sebesar satu atau 100 persen.

Rasio Efisiensi $=\frac{\text { BiayaYangDikeluarkanuntukMemungutPAD }}{\operatorname{Re} \text { alisasiPenerimaanPAD }}$

Kinerja Pemda dalam melakukan pemungutan pendapatan dikategorikan efisien apabila rasio yang dicapai kurang dari satu atau di bawah 100 persen.

Uji hipotesa dimaksudkan apakah adanya perbedaan antara sebelum dan sesudah pemberlakuan anggaran berbasis kinerja. Uji statistik untuk pengujian hipotesa digunakan distribusi $F$. Distribusi $F$ yaitu setiap distribusi tergantung pada derajat bebasnya. Derajat bebas terdiri dari derajat bebas pembilang yang diperoleh dari k-1, dimana $\mathrm{k}$ adalah jumlah perlakuan atau perbedaan yang akan diuji, dengan derajat bebas penyebut yang diperoleh dari $\mathrm{N}-1$, dimana $\mathrm{N}$ adalah jumlah total pengamatan dari seluruh perlakuan atau perbedaan. 


\section{PEMBAHASAN}

Berdasarkan data yang telah diperoleh dari bagian keuangan daerah Pemerintah Kota Kediri yang berupa laporan perhitungan Anggaran Pendapatan dan Belanja Daerah (APBD) tahun anggaran 2002, 2003, 2004, 2006, 2007, dan 2008 dapat dibuat perhitungan rasio kinerja keuangan daerah. Kemudian rasio kinerja keuangan tersebut digunakan sebagai dasar dalam perhitungan uji beda dengan menggunakan uji $\mathrm{F}$ untuk mengetahui perbedaan kinerja keuangan Pemerintah Kota Kediri sebelum dan sesudah diberlakukannya anggaran berbasis kinerja.

Dari rasio kemandirian keuangan daerah pada Tabel Rasio Kemandirian Keuangan Kota Kediri dapat diketahui bahwa pada periode sebelum pemberlakuan anggaran berbasis kinerja tingkat rasio menunjukkan angka yang berfluktasi, yaitu mengalami penurunan pada tahun 2002 yang menunjukkan angka $187 \%$ dan $81,7 \%$ pada tahun 2003, sedangkan pada tahun 2004 menunjukkan angka kenaikan yaitu Tabel 1. Rasio Kemandirian Keuangan Kota Kediri

\begin{tabular}{llll}
\hline \multicolumn{1}{c}{ Tahun } & \multicolumn{1}{c}{ PAD } & \multicolumn{1}{c}{$\begin{array}{c}\text { Bantuan } \\
\text { Pemerintah \& Pinjaman }\end{array}$} & $\begin{array}{c}\text { Rasio } \\
\text { Kemandirian }\end{array}$ \\
\hline 2002 & Rp. 21.246.976.875,97 & Rp. 11.343.226.430,00 & $81,7 \%$ \\
2003 & Rp. 26.209.849.527,16 & Rp. 32.073.047.410,00 & $117 \%$ \\
2004 & Rp. 37.442.390.788,34 & Rp. 32.027.868.760,00 & $227 \%$ \\
2006 & Rp. 52.906.292.845,54 & Rp. 23.352.682.658,00 & $333 \%$ \\
2007 & Rp. 72.485.751.709,60 & Rp. 21.770.873.754,00 & $330,3 \%$ \\
2008 & Rp. 72.955.454.942,86 & Rp. 22.090.070.491,00 & $113 \%$ \\
RATA-RATA & & & \\
Sebelum & Rp. 28.299.739.060,00 & Rp. 25.148.060.870,00 & $295 \%$ \\
Sesudah & Rp. 66.115.833.160,00 & Rp. 22.404.542.300,00 & \\
\hline Sumber: Laporan
\end{tabular}

Sumber: Laporan Perhitungan APBD Kota Kediri, diolah

Tabel 2. Rasio Desentralisasi Fiskal Kota Kediri

\begin{tabular}{llll}
\hline Tahun & PAD & Total Penerimaan Daerah & Rasio Desentralisasi Fiskal \\
\hline 2002 & Rp. 21.246.976.875,97 & Rp. 218.430.688.689,47 & $9,7 \%$ \\
2003 & Rp. 26.209.849.527,16 & Rp. 231.355.734.178,33 & $11,3 \%$ \\
2004 & Rp. 37.442.390.788,34 & Rp. 236.195.485.029,83 & $15,9 \%$ \\
2006 & Rp. 52.906.292.845,54 & Rp. 480.811.900.717,32 & $11 \%$ \\
2007 & Rp. 72.485.751.709,60 & Rp. 511.629.319.261,60 & $14,2 \%$ \\
2008 & Rp. 72.955.454.942,86 & Rp. 560.611.273.327,13 & $13 \%$ \\
RATA-RATA & & & \\
Sebelum & Rp. 28.299.739.060,00 & Rp. 228.660.635.900,00 & $9,8 \%$ \\
Sesudah & Rp. 66.115.833.160,00 & Rp. 517.684.164.400,00 & $12,8 \%$ \\
\hline
\end{tabular}

Sumber: Laporan Perhitungan APBD Kota Kediri, diolah
$117 \%$, yang berarti tingkat kenaikannya mencapai $35,3 \%$.

Sedangkan dari perhitungn rasio kemandirian keuangan Kota Kediri pada periode sesudah pemberlakuan anggaran berbasis kinerja dapat diketahui bahwa tingkat rasio juga menunjukkan angka yang berfluktasi, yaitu $227 \%$ pada tahun 2006 dan 333\% pada tahun 2007, yang berarti tingkat kenaikannya mencapai 106\%. Tetapi pada tahun 2008 menunjukkan angka $330,3 \%$ dan itu berarti mengalami penurunan sebesar $2,7 \%$.

Meskipun tingkat rasio kemandirian mengalami penurunan, tetapi penurunan rasio kemandirian pada periode setelah pemberlakuan anggaran berbasis kinerja lebih rendah apabila dibandingkan dengan tingkat penurunan pada sebelum pemberlakuan anggaran berbasis kinerja. Adapun rata-rata rasio kemandirian keuangan Kota Kediri mengalami peningkatan, yaitu $113 \%$ pada periode sebelum pemberlakuan anggaran berbasis kinerja dan meningkat menjadi $295 \%$ pada periode sesudah pemberlakuan anggaran berbasis kinerja. 
Kondisi menunjukkan tingkat kemandirian daerah Kota Kediri dalam mencukupi kebutuhan pembiayaan untuk melakukan tugas-tugas pemerintahan, pembangunan dan pelayanan sosial masyarakat cenderung mengalami kenaikan. Dilihat dari rata-rata pada Tabel Rasio Kemandirian Keuangan Kota Kediri, adanya peningkatan tingkat kemandirian antara sebelum pemberlakuan anggaran berbasis kinerja dengan sesudah pemberlakuan anggaran berbasis kinerja.

Pada tabel Rasio Desentralisasi Fiskal Kota Kediri dapat diketahui tingkat desentralisasi fiskal Kota Kediri pada periode sebelum pemberlakuan anggran berbasis kinerja menunjukkan angka kenaikan yaitu sebesar $9,7 \%$ pada tahun 2002, pada tahun 2003 naik menjadi 11,3\%, lalu pada tahun 2004 mengalami kenaikan lagi menjadi $15,9 \%$. Sedangkan pada periode sesudah pemberlakuan anggaran berbasis kinerja menunjukkan angka yang berfluktasi, yaitu sebesar $11 \%$ pada tahun 2006, pada tahun 2007 naik menjadi 14,2\%, pada tahun 2008 mengalami penurunan menunjukkan angka $13 \%$.

Nilai dari rasio desentralisasi fiskal dari tahun ke tahun pada periode sebelum pemberlakuan anggaran berbasis kinerja mengalami kenaikan, sedangkan pada periode sesudah pemberlakuan anggaran berbasis kinerja mengalami fluktuasi tahun ke tahun. Meskipun demikian, tetapi tingkat rataTabel 3. Rasio Efisiensi Kota Kediri

\begin{tabular}{|c|c|c|c|}
\hline Tahun & $\begin{array}{c}\text { Biaya } \\
\text { Pemungutan PAD }\end{array}$ & Realisasi PAD & $\begin{array}{c}\text { Rasio } \\
\text { Efisiensi }\end{array}$ \\
\hline 2002 & Rp. 530.077.598,50 & Rp. 21.246.976.875,97 & $2,49 \%$ \\
\hline 2003 & Rp. $762.459 .353,80$ & Rp. $26.209 .849 .527,16$ & $2,91 \%$ \\
\hline 2004 & Rp. $808.951 .304,90$ & Rp. 37.442.390.788,34 & $2,16 \%$ \\
\hline 2006 & Rp. 603.208.035,00 & Rp. 52.906.292.845,54 & $1,14 \%$ \\
\hline 2007 & Rp. 746.000.000,00 & Rp. 72.485.751.709,60 & $1,03 \%$ \\
\hline 2008 & Rp. $759.266 .635,40$ & Rp. 72.955.454.942,86 & $1,04 \%$ \\
\hline \multicolumn{4}{|l|}{ RATA-RATA } \\
\hline Sebelum & Rp. 700.496.085,70 & Rp. 28.299.739.060,00 & $2,47 \%$ \\
\hline Sesudah & Rp. $702.824 .890,10$ & Rp. $66.118 .833 .160,00$ & $1,06 \%$ \\
\hline
\end{tabular}

ratanya mengalami peningkatan, yaitu $9,8 \%$ pada periode sebelum pemberlakuan anggaran berbasis kinerja dan $12,8 \%$ pada periode sesudahnya.

Kondisi menunjukkan adanya peningkatan partisipasi, prakasa dan kreativitas masyarakat dalam pembangunan, serta pemerintah daerah Kota Kediri melakukan pemerataan hasil-hasil pembangunan di seluruh daerah, hal ini terlihat dari tingkat desentralisasi fiskal yang mengalami kenaikan antara sebelum pemberlakuan anggaran berbasis kinerja dengan sesudah pemberlakuan anggaran berbasis kinerja.

Jika semakin kecil rasio efisiensi berarti kinerja pemerintah daerah semakin baik. Pada Tabel rasio efisiensi mennnjukkan angka yang berfluktasi, pada tahun 2002 rasio efisiensi sebesar $2,49 \%$ dan mengalami kenaikan rasio efektivitas menjadi $2,91 \%$ yang berarti tingkat efisiensi mengalami penurunan. Pada tahun 2004 menjadi 2,16\%, tahun 2006 menjadi $1,14 \%, 1,03 \%$ pada tahun 2007 dan pada tahun 2008 sebesar $1,04 \%$. Angka rasio efisiensi dari tahun 2003 sampai tahun 2008 mengalami penurunan yang berarti kinerja pemerintah daerah Kota Kediri mengalami peningkatan.

Guna memperoleh ukuran yang lebih baik, rasio efisiensi perlu diperbandingkan dengan rasio efektivitas yang dicapai pemerintah daerah. 
Tabel 4. Rasio Efektivitas Kota Kediri

\begin{tabular}{|c|c|c|c|}
\hline Tahun & Realisasi PAD & Target PAD & $\begin{array}{c}\text { Rasio } \\
\text { Efektivitas }\end{array}$ \\
\hline 2002 & Rp. 21.246.976.875,97 & Rp. 15.660.194.825,07 & $135 \%$ \\
\hline 2003 & Rp. 26.209.849.527,16 & Rp. 30.452.333.897,30 & $86,1 \%$ \\
\hline 2004 & Rp. 37.442.390.788,34 & Rp. $29.378 .106 .703,89$ & $127 \%$ \\
\hline 2006 & Rp. 52.906.292.845,54 & Rp. 49.323.094.065,00 & $107 \%$ \\
\hline 2007 & Rp. $72.485 .751 .709,60$ & Rp. 68.007.922.654,58 & $106 \%$ \\
\hline 2008 & Rp. 72.955.454.942,86 & Rp. 66.049.571.499,54 & $110 \%$ \\
\hline RATA-RATA & & & \\
\hline Sebelum & Rp. 28.299.739.060,00 & Rp. 25.163.545.140,00 & $112 \%$ \\
\hline Sesudah & Rp. 66.115.833.160,00 & Rp. 61.126.862.730,00 & $108 \%$ \\
\hline
\end{tabular}

Angka rasio efektivitas pada Tabel Rasio Efektivitas Kota Kediri menunjukkan angka yang berfluktasi pada periode sebelum pemberlakuan anggaran berbasis kinerja yaitu $135 \%$ pada tahun 2002, pada tahun 2003 menurun menjadi $86,1 \%$ dan pada tahun 2004 mengalami kenaikan menjadi $127 \%$. Sedangkan pada periode sesudah pemberlakuan anggaran berbasis kinerja juga mengalami naik turun, pada tahun 2006 yaitu 107\%, pada tahun 2007 mengalami penurunan $106 \%$ dan pada tahun 2008 mengalami kenaikan 110\%. Dalam rasio efektivitas jika angka rasio efektivitas semakin tinggi maka kemampuan daerah semakin baik. Sedangkan pada Tabel 4 rata-rata menunjukkan antara tahun sebelum dan sesudah pemberlakuan anggaran berbasis kinerja mengalami penurunan yatu dari $112 \%$ pada sebelum diberlakukannya anggran berbasis kinerja, dan $108 \%$ pada periode sesudah diberlakukannya anggran berbasis kinerja.

Dari seluruh hasil uji beda dengan menggunakan alat distribusi $\mathrm{F}$ telah diperoleh hasil bahwa tingkat kemandirian keuangan daerah, tingkat efisiensi dan efektifitas diperoleh hasil yang signifikan, sedangkan tingkat desentralisasi fiskal dari uji $\mathrm{F}$ diperoleh hasil yang tidak signifikan.
Kinerja keuangan pemerintah Kota Kediri dilihat dari sisi kemandirian keuangan daerah pada periode sebelum dan sesudah pemberlakuan anggaran berbasis kinerja tidak mengalami perbedaan yang signifikan. Dilihat dari rata-rata pada Tabel 4 adanya peningkatan tingkat kemandirian antara sebelum pemberlakuan anggaran berbasis kinerja dengan sesudah pemberlakuan anggaran berbasis kinerja (113\% pada periode sebelum pemberlakuan anggaran berbasis kinerja dan meningkat menjadi $295 \%$ pada periode sesudah pemberlakuan anggaran berbasis kinerja). Sedangkan dengan uji $\mathrm{F}$ menunjukkan $\mathrm{F}$ (hitung) $=3437,674$ dan $\mathrm{F}($ tabel $)=5,99 ; \mathrm{F}$ (hitung) $>\mathrm{F}$ (tabel) berarti $\mathrm{F}$ (hitung) berada di daerah penolakan $\mathrm{H}_{\mathrm{o}}$ dan menerima $\mathrm{H}_{\mathrm{a}}$, hal ini berarti adanya perbedaan antara sebelum dan sesudah pemberlakuan anggaran berbasis kinerja.

Kondisi ini dapat diartikan bahwa adanya peningkatan dalam hal partisipasi masyarakat Kota Kediri dalam pembangunan daerah, yaitu dalam hal pembayaran pajak dan retribusi yang merupakan komponen utama PAD pada waktu sesudah pemberlakuan anggaran berbasis kinerja. Kemandirian keuangan daerah ditunjukkan oleh besar kecilnya pendapatan asli daerah dibandingkan dengan pendapatan daerah yang berasal dari sumber lain, misalnya bantuan 
pemerintah pusat ataupun dari pinjaman (Halim 2001:128). Dilihat dari laporan Anggran Pendapatan Belanja Daerah (APBD) antara sebelum dan sesudah diberlakukannya anggaran berbasis kinerja pendapatan asli daerah lebih besar dari bantuan pemerintah pusat ataupun dari pinjaman, pada periode sebelum diberlakuakannya masih terdapat pendapat yang berasal dari pinjaman, sedangkan pada periode sesudah diberlakukannya anggaran berbasis kinerja sudah tidak ada pendapatan yang berasal dari pinjaman. Pada periode sebelum dan sesudah pemberlakuan anggaran berbasis kinerja pendapatan yang berasal dari bantuan pemerintah pusat tetap ada, tetapi jumlahnya berkurang dari pada periode sebelum diberlakukannya anggaran berbasis kinerja.

Apabila kinerja keuangan dilihat dari sisi desentralisasi fiskal, dari perhitungan rasio tingkat desentralisasi fiskal pada Tabel 3 menunjukkan bahwa adanya peningkatan dilihat dari rataratanya, yaitu $9,8 \%$ pada periode sebelum pemberlakuan anggaran berbasis kinerja dan $12,8 \%$ pada periode sesudah pemberlakuan anggaran berbasis kinerja. Apabila dilihat dari sisi uji $\mathrm{F}$ menunjukkan $\quad \mathrm{F}$ (hitunng) $=0,000$ sedangkan $\quad \mathrm{F}($ tabel $)=5,99 ; \quad$ maka $\mathrm{F}$ (hitung) $<\mathrm{F}$ (tabel) yang berarti $\mathrm{F}$ (hitung) berada di daerah menerima $\mathrm{H}_{\mathrm{o}}$ dan menolak $\mathrm{H}_{\mathrm{a}}$. Hal tersebut berarti bahwa kemampuan pemerintah Kota Kediri dalam melaksanakan wewenang dan tanggung jawab dalam penyelenggaraan pembangunan dari pemerintah pusat relatif tidak mengalami peningkatan, tetapi juga tidak mengalami penurunan. Dengan kata lain bahwa pemberlakuan anggaran berbasis kinerja tidak berpengaruh secara signifikan terhadap kinerja keuangan Pemerintah Kota Kediri dalam penyelenggaraan pembangunan.
Inti dari maksud desentralisasi fiskal adalah sebagai pelimpahan kewenangan di bidang penerimaan (keuangan), dari sistem yang tersentralisasi oleh level pemerintahan di atasnya (Rossen, 2002, Boex, 2001, dan Bird, 2000). Dengan diserahkannya wewenang ke pemerintah daerah diharapkan akan mendorong peningkatan efisiensi ekonomi, khususnya di sektor publik dan dapat mendorong pertumbuhan ekonomi daerah. Semakin besar nilai derajat fiskal, maka semakin besar kemandirian daerah dalam pendanaan pelaksanaan tugas daerah baik kegiatan rutin maupun pembangunan. Menurut Dillinger, dalam Sidik (2001), pada dasarnya terdapat empat jenis desentralisasi salah satunya yaitu, desentralisasi fiskal adalah pelimpahan wewenang dalam mengelola sumber-sumber keuangan yang mencakup Self-financing atau cost recovery dalam pelayanan publik terutama melalui retribusi daerah, Cofinancing atau co-production, dimana pengguna jasa berpartisipasi dalam bentuk pembayaran jasa, transfer dari pemerintah pusat terutama berasal dari Dana Alokasi Umum (DAU), Dana Alokasi Khusus (DAK), sumbangan darurat, serta pinjaman daerah (sumber daya alam).

Berdasarkan hasil uji $F$ tidak adanya perbedaan tingkat desentralisasi fiskal antara sebelum dan sesudah pemberlakuan anggaran berbasis kinerja. PAD dan bagi hasil bukan pajak meripakan bagian dari komponen pendukung dalam penyelenggaraan pembangunan daerah. Dilihat dari APBD 2002-2004 yang merupakan periode sebelum pemberlakuan anggaran berbasis kinerja pos bagi hasil bukan pajak cenderung mengalami penurunan, pada tahun 2002 sebesar Rp. 1.507.437.976,42, pada tahun 2003 sebesar Rp. 1.125.749.522,00 dan pada 
tahun 2004 menjadi Rp. 684.209.385,00. Sedangkan PAD mengalami peningkatan dari tahun 2002-2004. Pada periode sesudah pemberlakuan anggaran berbasis kinerja (dilihat dari APBD 2006-2008) bagi hasil bukan pajak cenderung tidak mengalami penurunan, dengan kata lain tidak terdapat perbedaan secara signifikan antara sebelum dan sesudah pemberlakuan anggaran berbasis kinerja, sedangkan PAD mengalami peningkatan. Penurunan bagi hasil bukan pajak terkait dengan semakin berkurangnya kuantitas dan kualitas Sumber Daya Alam (SDA).

Kinerja keuangan pemerintah daerah Kota Kediri dilihat dari sisi tingkat efisiensi dan efektivitas, untuk memperoleh ukuran yang lebih baik rasio efisiensi perlu dipersandingkan dengan rasio efektivitas yang dicapai pemerintah daerah (Halim, 2004:152). Dari hasil perhitungan dengan rasio keuangan menunjukkan angka rata-rata $2,47 \%$ saat periode sebelum pemberlakuan anggaran berbasis kinerja dan $1,06 \%$ saat periode sesudah pemberlakuan anggaran berbasis kinerja pada rasio efisiensi, sedangkan rata-rata rasio efektivitas menunjukkan angka rata-rata $112 \%$ saat periode sebelum diberlakukannya anggaran berbasis kinerja dan $108 \%$ saat sesudah diberlakukannya anggaran berbasis kinerja. Dari hasil uji beda baik tingkat efisiensi maupun tingkat efektivitas, menunjukkan hasil yang sama yaitu signifikan. Hasil uji $\mathrm{F}$ untuk tingkat efisiensi menunjukkan $\mathrm{F}$ (hitung) $=55,034$ dengan $\quad \mathrm{F}($ tabel $)=5,99 ; \quad$ maka $\mathrm{F}$ (hitung) $>\mathrm{F}$ (tabel) yang berarti $\mathrm{F}$ (hitung) berada di daerah penolakan $\mathrm{H}_{\mathrm{o}}$ dan menerima $\mathrm{H}_{\mathrm{a}}$. Sedangkan tingkat efektivitas hasil uji $\mathrm{F}$ menunjukkan $\mathrm{F}$ (hitung) $>\mathrm{F}$ (tabel); $\mathrm{F}$ (hitung) $=124,096$ dan $\mathrm{F}($ tabel $)=5,99$ yang berarti $\mathrm{F}$ (hitung) berada di daerah penolakan $\mathrm{H}_{\mathrm{o}}$ dan menerima $\mathrm{H}_{\mathrm{a}}$.
Dilihat dari tingkat rasio efisiensi, pada saat biaya pemungutan untuk merealisasikan PAD mengalami peningkatan pada tahun sebelum pemberlakuan anggaran berbasis kinerja, yaitu sebesar 43,84\% dari tahun 2002 ke tahun 2003, pada tahun 2003 ke tahun 2004 mengalami kenaikkan sebesar $6,10 \%$.

Pada Periode sesudah pemberlakuan anggaran berbasis kinerja biaya pemungutan mengalami penurunan jika dibandingkan dengan periode sebelum pemberlakuan anggaran berbasis kinerja yaitu dari tahun $2006 \mathrm{ke}$ tahun 2007 sebesar 23,67\%; dari tahun 2007 ke tahun 2008 sebesar 1,78\%. Tetapi jumlah realisasi atas PAD justru mengalami kenaikan tiap tahunnya antara sebelum dan sesudah pemberlakuan anggaran berbasis kinerja yaitu dari tahun 2002 ke 2003 mengalami kenaikkan $23 \%$, pada tahun 2004 sebesar 43\%. Sedangkan pada tingkat efektivitas, pada saat target PAD mengalami fluktuasi, pada periode sebelum pemberlakuan anggaran berbasis kinerja mengalami kenaikkan.

Sedangkan pada perode sesudah diberlakukannya anggaran berbasis kinerja mengalami penurunan pada tahun 2007 sebesar Rp. 68.007.922.654,58 dan pada tahun mengalmi penurunan menjadi Rp. 66.049.571.499,54, tetapi kondisi riil yang terjadi justru sebaliknya, yaitu adanya peningkatan realisasi PAD antara sebelum dan sesudah pemberlakuan anggaran berbasis kinerja.

Pada tingkat efektivitas apabila dilihat dengan perhitungn rasio keuangan tingkat rasio efektivitas mengalami fluktuasi antara sebelum dan sesudah pemberlakuan anggaran berbasis kinerja, dilihat rata-rata efektivitas sebelum dan sesudah pemberlakuan anggaran berbasis kinerja mengalami penurunan. Menurut Halim (2007:234), 
semakin tinggi rasio efektivitas, maka kemampuan daerah pun semakin baik. Hal ini menunjukkan bahwa efektivitas pemerintahan mengalami penurunan. Rasio efektivitas perlu dipersandingkan dengan rasio efisiensi guna memperoleh ukuran yang lebih baik. Dari hasil perhitungan rasio keuangan dan uji $\mathrm{F}$ menunjukkan hasil yang baik, efektivitas dan efisiensi berjalan dengan baik.

Hasil dari penelitian antara sebelum dan sesudah pemberlakuan anggaran berbasis kinerja terhadap kinerja keuangan di Kota Kediri dengan menggunakan uji $\mathrm{F}$, secara keseluruhan mengalami peningkatan secara signifikan, kecuali pada tingkat desentralisasi fiskal tidak mengalami peningkatan.

Dari beberapa kondisi diatas, dapat diketahui bahwa Pendapatan Asli Daerah Kota Kediri tahun 2006 dianggarkan sebesar Rp. 49.323.094.065,00, sedangkan yang terealisasi sebesar Rp. 52.906.292.845,54 atau $107 \%$ dari anggaran. Pada tahun 2007 melebihi target yang ditetapkan, dianggarkan sebesar Rp. 68.007.922.654,58 terealisasi sebesar Rp. $72.485 .751 .709,60$ atau $106 \%$ dari anggaran. Sedangkan pada tahun 2008 dianggarkan sebesar Rp. 66.049.571.499,54 yang terealisasi sebesar Rp. 72.955.454.942,86 atau $110 \%$ dari anggaran.

Sistem pengendalian intern menunjukkan bahwa yang perlu mendapatkan perhatian antara lain penggunaan langsung atas penerimaan retribusi pelayanan kesehatan serta pemungutan retribusi/pajak daerah tidak sesuai ketentuan yang berlaku, realisasi belanja barang-bahan bakar minyak/gas pada Dinas Kebersihan Lingkungan Hidup. Berdasarkan hasil pemeriksaan BPK-RI, kelemahan-kelemahan tersebut dapat dirinci sebagai berikut.
Sebagaimana dituangkan dalam Hasil Pemeriksaan Kepatuhan Nomor 1, Realisasi Belanja Barang-Bahan Bakar Minyak/Gas pada Dinas Kebersihan dan Lingkungan Hidup tidak sesuai peruntukkannya sehingga mengakibatkan kerugian daerah sebesar Rp. 369.578.700,00;

Sebagaimana dituangkan dalam Hasil Pemeriksaan Kepatuhan Nomor 2, Realisasi belanja barang-bantuan transpor Rapat Koordinasi Muspida sebesar Rp. 580.000.000,00 tidak didukung dengan bukti yang lengkap dan sah mengakibatkan realisasi belanja Rapat Koordinasi Muspida tidak dapat diyakini kebenarannya dan merugikan daerah sebesar Rp. 580.000.000,00;

Sebagaimana dituangkan dalam Hasil Pemeriksaan Kepatuhan Nomor 3, Pembebanan Belanja Hibah pada Belanja Modal Gedung dan Bangunan sebesar Rp4.507.021.321,00 tidak tepat mengakibatkan realisasi Gedung Dan Bangunan disajikan lebih tinggi dan Belanja Hibah disajikan lebih rendah sebesar Rp4.507.021.321,00;

Sebagaimana dituangkan dalam Hasil Pemeriksaan Kepatuhan Nomor 4, Penerimaan Bantuan Keuangan dan Hibah dalam bentuk uang sebesar Rp. 2.079.346.000,00 tidak disajikan dalam Laporan Realisasi Anggaran mengakibatkan realisasi Lain-Lain Pendapatan Daerah Yang Sah sebesar Rp. 2.079.346.000,00, Belanja Modal sebesar Rp. 1.387.996.000,00 (Rp. 340.000.000,00 + Rp. 1.047.996.000,00) dan Belanja Barang dan Jasa sebesar Rp. 691.350.000,00 (Rp. 341.350.000,00 + Rp. 350.000.000,00) disajikan lebih rendah;

Sebagaimana dituangkan dalam Hasil Pemeriksaan Kepatuhan Nomor 6, Aset Tanah yang disajikan seluas \pm 38.578 M2 senilai Rp1.213.041.000,00 belum jelas status kepemilikannya mengakibatkan aset tanah sebesar 
Rp1.213.041.000,00 tidak dapat diyakini kewajarannya;

Sebagaimana dituangkan dalam Hasil Pemeriksaan Kepatuhan Nomor 9, Dana Bantuan Tunai Program JPK-MM TA 2007 sebesar Rp1.191.046.160,00 tidak diperhitungkan dalam APBD, dan sisa dana sebesar Rp1.007.274.225,00 tidak disajikan dalam Neraca Per 31 Desember 2007 mengakibatkan realisasi Pendapatan Retribusi Pelayanan Kesehatan sebesar Rp1.191.046.160,00 dan Belanja Barang sebesar Rp183.771.935,00 disajikan lebih rendah, dan Kas kurang disajikan sebesar Rp1.007.274.225,00;

Sebagaimana dituangkan dalam Hasil Pemeriksaan Kepatuhan Nomor 13, Pembebanan Belanja Modal Instalasi Listrik dan Telepon pada Belanja Modal Aset Tetap Lainnya sebesar Rp1.061.375.000,00 tidak tepat mengakibatkan realisasi Belanja Modal Jalan, Irigasi dan Jaringan disajikan lebih rendah dan realisasi Belanja Modal Aset Tetap Lainnya disajikan lebih tinggi sebesar Rp1.061.375.000,00;

Sebagaimana dituangkan dalam Hasil Pemeriksaan Kepatuhan Nomor 14, Realisasi Belanja Modal Gedung dan Bangunan Fasilitas Umum kegiatan stimulan Pembangunan Desa sebesar Rp1.751.192.250,00 tidak didukung dengan bukti yang lengkap mengakibatkan realisasi Belanja Modal Gedung dan Bangunan sebesar Rp1.751.192.250,00 tidak dapat diyakini kewajarannya.

Langkah konkrit yang dapat dilakukan oleh Pemerintah Kota Kediri yaitu memperhatikan ketentuan yang berlaku dalam pembagian biaya upah pemungutan, pengelolaan Pasar Bandar ditertibkan sesuai ketentuan yang berlaku, lebih memperhatikan pelaksanaan pekerjaan pengadaan rambu-rambu lalu lintas pada Dinas Perhubungan.
Sebagai upaya peningkatan kinerja keuangan Pemerintah Kota Kediri harus ada pengarahan dan pendampingan yang lebih intensif terhadap proses penyusunan dan pelaksanaan Anggaran Pendapatan Belanja Derah yang didasarkan pada anggaran berbasis kinerja, baik dari pusat maupun dari lembaga-lembaga terkait.

\section{PENUTUP}

Kemandirian keuangan pemerintah Kota Kediri dilihat dari hasil perhitungan laporan keuangan rasio kemandirian menunjukkan hasil rata-rata $113 \%$ pada periode sebelum pemberlakuan anggaran berbasis kinerja dan meningkat menjadi $295 \%$ pada periode sesudah pemberlakuan anggaran berbasis kinerja, sedangkan hasil uji $F$ menunjukkan $\mathrm{F}$ (hitung) $=3437,674$ dan $\mathrm{F}$ (tabel) $=5,99$; $\mathrm{F}$ (hitung) $>\mathrm{F}$ (tabel) berarti $\mathrm{F}$ (hitung) berada di daerah penolakan $\mathrm{H}_{\mathrm{o}}$ dan menerima $\mathrm{H}_{\mathrm{a}}$, hal ini berarti adanya perbedaan antara sebelum dan sesudah pemberlakuan anggaran berbasis kinerja. Kondisi ini dapat diartikan bahwa adanya peningkatan dalam hal partisipasi masyarakat Kota Kediri dalam pembangunan daerah, yaitu dalam hal pembayaran pajak dan retribusi yang merupakan komponen utama PAD pada waktu sesudah pemberlakuan anggaran berbasis kinerja.

Sedangkan desentralisasi fiskal dilihat dari uji $\mathrm{F}$ menunjukkan $\mathrm{F}$ (hitunng) $=0,000 \quad$ sedangkan $\mathrm{F}($ tabel $)=5,99$; maka $\mathrm{F}$ (hitung) $<\mathrm{F}($ tabel $)$ yang berarti $\mathrm{F}$ (hitung) berada di daerah menerima $\mathrm{H}_{\mathrm{o}}$ dan menolak $\mathrm{H}_{\mathrm{a}}$, hal tersebut berarti bahwa kemampuan pemerintah Kota Kediri dalam melaksanakan wewenang dan tanggung jawab dalam penyelenggaraan pembangunan dari pemerintah pusat relatif tidak mengalami peningkatan, tetapi juga tidak mengalami penurunan. Dengan kata lain bahwa pemberlakuan 
anggaran berbasis kinerja tidak berpengaruh secara signifikan terhadap kinerja keuangan Pemerintah Kota Kediri dalam penyelenggaraan pembangunan.

Tingkat efisiensi PAD pemerintah Kota Kediri antara sebelum dan sesudah pemberlakuan anggaran berbasis kinerja dilihat dari uji $F$ menunjukkan $\mathrm{F}$ (hitung) $=55,034$ dengan $\mathrm{F}($ tabel $)=5,99$; maka $\mathrm{F}$ (hitung) $>\mathrm{F}$ (tabel) yang berarti $\mathrm{F}$ (hitung) berada di daerah penolakan $\mathrm{H}_{\mathrm{o}}$ dan menerima $\mathrm{H}_{\mathrm{a}}$. Dari hasil perhitungan dengan rasio keuangan menunjukkan angka rata-rata $2,47 \%$ saat periode sebelum pemberlakuan anggaran berbasis kinerja dan $1,06 \%$ saat periode sesudah pemberlakuan anggaran berbasis kinerja. Kondisi ini berarti terjadinya perbedaan antara sebelum dan sesudah pemberlakuan anggaran berbasis kinerja. Guna memperoleh ukuran yang lebih baik rasio efisiensi perlu dipersandingkan dengan rasio efektivitas yang dicapai pemerintah daerah (Halim, 2004:152).

Tingkat efektivitas PAD pemerintah Kota Kediri apabila dilihat dari uji $F$ menunjukkan $\mathrm{F}$ (hitung) $>\mathrm{F}($ tabel $) ; \quad \mathrm{F}($ tabel $)=5,99$ dan $\mathrm{F}$ (hitung) $=124,096$ berarti $\mathrm{F}$ (hitung) berada di daerah penolakan $\mathrm{H}_{\mathrm{o}}$ dan menerima $\mathrm{H}_{\mathrm{a}}$. Rasio efektivitas perlu dipersandingkan dengan rasio efisiensi guna memperoleh ukuran yang lebih baik. Dilihat dari tingkat efisiensi dan tingkat efektivitas menunjukkan hasil yang sama yaitu signifikan. Adanya perbedaan tingkat efektifitas PAD dan efisiensi PAD Pemerintah Kota Kediri antara sebelum dan sesudah pemberlakuan anggaran berbasis kinerja. Hasil dari penelitian antara sebelum dan sesudah pemberlakuan anggaran berbasis kinerja terhadap kinerja keuangan di Kota Kediri dengan menggunakan uji F, secara keseluruhan mengalami peningkatan secara signifikan, kecuali pada tingkat desentralisasi fiskal tidak mengalami peningkatan.

\section{DAFTAR PUSTAKA}

Arsyad Lincolin dan Soeratno, 1993. Metodologi Penelitian untuk Ekonomi dan Bisnis, Edisi Revisi, (UPP) AMP YKPN. Yogyakarta.

Bastian, Indra.2006. Sistem Akuntansi Sektor Publik, Edisi 2, Salemba Empat. Jakarta

- 2006. Sistem Perencanaan dan Penganggaran Pemerintah Daerah di Indonesia, Salemba Empat. Jakarta.

Devas, Nick.1989. Keuangan Pemerintah Daerah di Indonesia, UI press. Jakarta.

Halim Abdul, 2004. Bunga Rampai: Manajemen Keuangan Daerah,Edisi Revisi, (UPP) AMP YKNPN. Yogyakarta. , 2004. Akuntansi Sektor Publik Akuntansi Keuangan Daerah, Edisi Revisi, Salemba Empat. Jakarta.

2007. Akuntansi Sektor Publik Akuntansi Keuangan Daerah, Edisi 3,Salemba Empat. Jakarta

Jones, Rowan dan Maurice Pendlebury, 1996, $4^{\text {th }}$ ed. Public Sector Accounting, Pitman Publishing.

Mardiasmo, 2002. Otonomi \& manajemen Keuangan Daerah, Andi.Yogyakarta.

—2002. Akuntansi Sektor Publik, Andi. Yogyakarta. 
Mello and Barenstein. 2006. Fiscal responsibility legislation and fiscal adjustment. Penerbit World Bank Publications. Washington DC.

.2001. Fiscal Decentralization and Governance: a cross-country analysis. IMF working paper No. WP/01/71 IMF.

Nordiawan Deddi, 2006, Akuntansi Sektor Publik, Salemba Empat. Jakarta.

Rahmawati, 2007, Akuntansi Pemerintahan, Salemba Empat. Jakarta.

Purwanto \& Suharyadi, 2004, Statistik Untuk Ekonomi \& Keuangan Modern, Salemba Empat. Jakarta.

Ulum Ihyaul, 2004.Akuntansi Sektor Publik, UMM Pres. Malang.

Analisis Kemampuan Keuangan Daerah. (http://www.deneprairie.com). Diakses 20 Januari 2009

Realisasi Anggaran Pendapatan dan Belanja Daerah (APBD),20002006.(http://www.djdkpd.or.id). Diakses 2008.

Penerapan Penganggaran Berbasis Kinerja di Indonesia. (http://www.bppk.depkeu.go.id). Diakses 9 februari 2009.

Perencanaan, Penganggaran, Pelaksanaan, Penatausahaan dan Pengawasan Keuangan Daerah. (http://www.deneprairie.com). Diakses 20 Januari 2009. 
